Original Research Paper

\title{
Anti-mollusk Selectivity of Jayanti Plant (Sesbania sesban L., Merr) for the Control of Golden Snails, a Pest of Paddy
}

\author{
Suripto $^{1^{*} \text {, Gunawan, E.R. }}{ }^{2}$, Tresnani, G. ${ }^{3}$, Jupri, A. ${ }^{4}$ \\ ${ }^{1}$ Study Program of Environmental Science of the Faculty of Mathematics and Natural Sciences, University of \\ Mataram, Indonesia \\ ${ }^{2}$ Chemistry Study Program of the Faculty of Mathematics and Natural Sciences, University of Mataram, \\ Indonesia \\ ${ }^{3}$ Biology Study Program of the Faculty of Mathematics and Natural Sciences, University of Mataram, \\ Indonesia \\ ${ }^{4}$ Study Program of Environmental Science of the Faculty of Mathematics and Natural Sciences, University of \\ Mataram, Indonesia
}

\author{
Article History \\ Received : August 28 $8^{\text {th }}, 2021$ \\ Revised : September $10^{\text {th }}, 2021$ \\ Accepted : September $17^{\text {th }}, 2021$ \\ Published : September $30^{\text {th }}, 2021$ \\ *Corresponding Author: \\ Suripto, \\ Environmental Sciences Study \\ Program Faculty of Mathematics \\ and Natural Sciences, University \\ of Mataram, Indonesia; \\ Email: suriptobio@unram.ac.id
}

\begin{abstract}
Pest control is an essential aspect of rice cultivation. The golden snail (Pomacea speciosa) is one of the pests in rice fields. Damage to rice plants due to golden snail attacks has occurred in several provinces in Indonesia and several countries such as the Philippines, Thailand, Japan, and Malaysia. Various steps to control golden snails have been carried out, both mechanically, biologically, and chemically. However, each biological and mechanical control of golden snails is impractical to apply to very large rice fields. Meanwhile, the control of golden snails using synthetic molluscicides such as Brestan and Dimotrin is minimal because it can pollute the environment and cause the death of fish and the rice plant itself. To suppress the emergence of environmental pollution problems in overcoming this golden snail, natural molluscicides from plant materials are studied. Several plant species have been known to have anti-mollusk properties, one of which potentially is the Jayanti plant $\{$ Sesbania sesban (L.) Merr. $\}$. This study aimed to evaluate the anti-mollusk performance of S. sesban for controlling golden snails, a pest of rice plants. The dry powder of S. sesban leaves was extracted in stages with a series of solvents of petroleum ether, chloroform, and ethanol to obtain an extract fraction that was selected as a mollucicide. Each extract fraction produced was tested for its toxicity to the gold snail, carp, rice germination, and rice plant growth. Data on the mortality of golden snail and carp fish, the percentage of germination inhibition, and rice growth were processed by probit analysis, respectively. The outputs of the analysis were $\mathrm{LC}_{50}$ of each extract fraction for golden snails and carp. The ratio of $\mathrm{LC}_{50}$ for golden snail with $\mathrm{LC}_{50}$ for carp indicated each extract fraction's physiological selectivity of anti-mollusk properties. The results showed that the highest lethal toxicity to gold snails was indicated by the extract fraction-ethanol, while to carp, it was indicated by the extract fraction-chloroform. Each extract fraction of $S$. sesban leaves did not inhibit the germination and growth of rice plants. The extract fraction- ethanol had the highest anti-mollusk selectivity compared to the other two fractions. Bioactive examination showed triterpene saponins from the extract of $S$. sesban leaves, with the highest relative levels in the ethanol fraction compared to the other two extract fractions.
\end{abstract}

Keywords : Anti-mollusk selectivity, Goldfish, Glden snail, Paddy, Sesbania sesban L. (Merr.) 


\section{Introduction}

In rice cultivation, pest control is a very important aspect. According to The Community Guidance Control Agency, The Ministry of Agriculture, rice production is determined by the success of the pest control component by $30 \%$. One type of pest that is relatively new to rice plants is the golden snail. Damage to rice plants due to golden snail attacks has occurred in several countries, such as the Philippines, Taiwan, Thailand, Malaysia, and Japan (Suripto et al., 2015).

In Indonesia, golden snails were originally cultivated for decoration in aquariums which were then kept in ponds for human consumption. But now the golden snail has spread to the rice fields, and in several provinces such as Aceh, South Sumatra, Jambi, Central Java, Bali, and West Nusa Tenggara, the golden snail is a pest of rice plants (Cybermedia, 2017; Guerrero, 2019; Munandar, 2013). Until now, golden snail attacks on hundreds of hectares of rice plants are reported to still occur in the areas mentioned above and even occur in other areas where this pest was not attacked before. The attack of the golden snail usually expands as it rains. The golden snail population can decrease during a prolonged dry season, but after the rains begin to fall, the gold snail attack spreads again (Adalla \& Morrallo-Rejeus, 2019; Edra, 2019; Lacanilao, 2020).

Various steps to control golden snails in rice fields have actually been carried out. Mechanical and biological control of golden snails, as has been done in the Philippines by installing egg traps, direct collection and deployment of ducks to rice fields, is felt to be less practical, because golden snails have spread and occupy a very large area (Sumangil, 2019). Chemical control of golden snails has also been carried out, among others by using Brestan (triphenyl-tin acetate) and Dimotrin (hydrochloride). However, the use of these compounds must be limited because they can pollute rivers, ponds, and waterways in the fields and cause the death of fish and other livestock. To suppress the emergence of environmental pollution problems in controlling the golden snail pest of rice plants, it is necessary to study the possibility of using molluscides from natural plant materials. Several tropical plants have been examined to have anti-mollusk activity. Groups of compounds from plants that have been identified as active anti-mollusks are saponins, tannins, alkaloids, and flavonoids (Kloos \& McCullough, 2017). The Jayanti plant (Sesbania. sesban) is reported to have anti-mollusk activity from several tropical plant species.

The leaf extract of $S$. sesban has been shown to be lethally toxic to the freshwater snails Biompalaria glabrata and Bulinus truncatus (Duncan, 2017). Several fractions of the leaf extract of S. sesban have also been reported to be lethally toxic with varying $\mathrm{LC}_{50}$ to the golden snail (Pomacea sp. ) (Sturrock \& Duncan, 2017). However, the selectivity of anti-mollusks, both physiologically and ecologically, of the Jayanti plant for controlling golden snail pests of rice plants is not known. And during the storage period of the material before extraction, it is also not known how the development of production technology and the application of natural molluscicide from the $S$. sesban plant is modified so that it is "feasible" for farmers until now has not been studied.

In the first year of research, a laboratory evaluation of the anti-mollusk properties of the $\mathrm{S}$. sesban leaf extract fractions was carried out with the outputs of the analysis including:

1. Ecologically selectivity of anti-mollusk leaf extract of the most physiologically selective $S$. sesban leaf extract for the control of rice snail pests.

2. Feasibility of manufacture and application of molluscicide from Jayanti plant ( $S$. sesban) for farmers to control golden snails, pests of rice plants.

\section{Materials and Methods}

Jayanti plant ( $S$. sesban) was selected as a source of natural molluscicides based on the following considerations:

1. Jayanti plants have many characteristics that match the basic characteristics of plant selection for natural sources of molluscicides, as proposed by Edra (2019) and Farnsworth et al. (2017), among others, that plants are known to have antimollusk potential, plants are available locally, easy to grow or cultivated by farmers, and active ingredients can be extracted with simple equipment and technology. 
2. The active ingredient of the mollucicide from the $S$. sesban plant comes from the class of saponin compounds. This group of compounds is polar, easily soluble in water so that the method of withdrawal and application is "feasible" for farmers. Apart from that, this group of compounds is easily degraded after application so that the use of natural mollucicides is environmentally safe (Kloos, H. \& F.S. McCullough, 2017; Suripto et al., 2015).

Jayanti (S. sesban) plants that exist in rice fields in the Lombok Island area are determined by species in the field using the determination key book from Backer \& van den Brink 1965 (Suripto et al., 2015). The leaves of plants that have been determined as S. sesban were collected (from plants that were two years old or more, where the plants were able to produce secondary metabolites, including the saponins). After being "air-dried," the leaves of $S$. sesban were ground, and the resulting dried leaf powder (simplicia) was ready for extraction.

The golden snails used in this study were collected from rice fields in Tanjung, West Lombok. This golden snail is bred from a ferocious type with the characteristics of clumps of red eggs, dull yellow shell color, short shell towers with deep canals. Goldfish were collected from a livestock pond in Sayang-Sayang Village, West Lombok.

For the biological test, the gold snail and carp used were of equal age and size, i.e., the golden snail was about one month old with a shell diameter of about $1 \mathrm{~cm}$, while the Goldfish was about two months old and weighed about 80 grams. Before the biological test was carried out, all test animals were acclimatized for $3 \times 24$ hours under the same conditions as the experimental conditions in the aquarium. For the biological test on the growth of rice plants, rice cultivar IR-64 was used.

\section{Extraction of Anti Mollusk Active Compounds from $S$. sesban Plant Leaves}

In order to extract the anti-mollusk active compound from the leaves of S. Sesban, a gradual (liquid-solid) extraction will be carried out, using a series of solvents with increasing polarity successively, namely petroleum ether, chloroform, and ethanol. The choice of solvent based on the level of polarity aims to dissolve all classes of active compounds from S. sesban leaves according to their polarity. Each level of extraction was carried out using the dry powder maceration technique (simplicia) of S. Sesban leaves, followed by soxhletation according to the procedure developed by Hostettmann \& Tomimori (2012).

Pure extracts from each fraction were obtained by evaporating the solvent used at the respective extraction level, using a vacuum rotary evaporator, and after being transferred to a cup, the resulting viscous extract was further concentrated by using the extract concentration technique in the evaporation chamber. The resulting pure extract (in the form of a paste) is put into a dark bottle and is ready for use in bioassays. The workflow chart for the liquid-solid extraction of S. sesban leaves in stages can be seen in Figure 2.

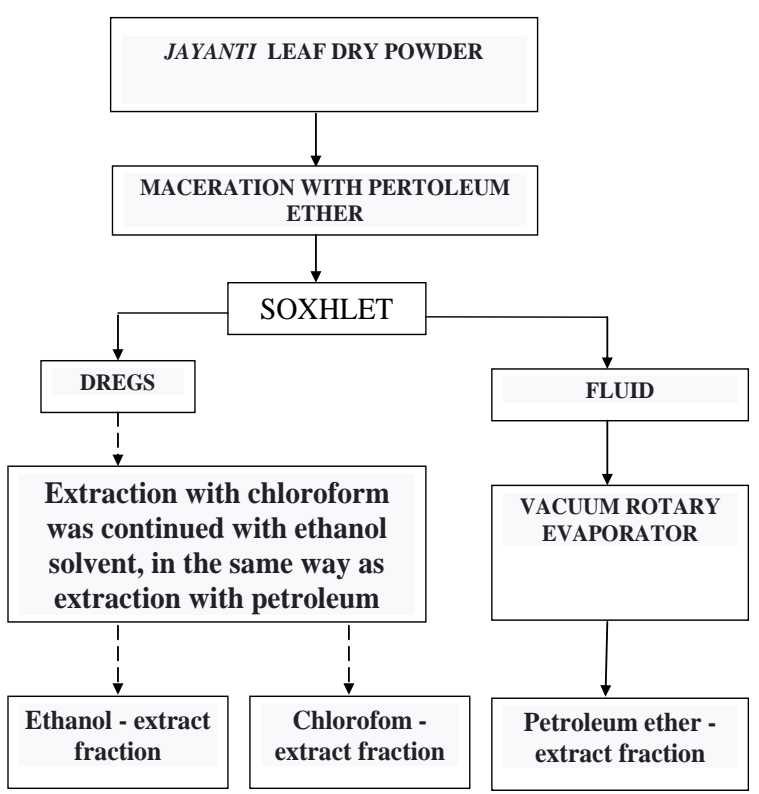

Figure 2. Flow chart of liquid-solid extraction in stages from jayanti ( $S$. sesban ) leaves with increasing solvent polarity series.

Before being used for biological testing, each of the resulting S. sesban leaf extract fractions was examined for saponin content using thin-layer chromatography (TLC), according to the method developed by Hamburger \& Hostettmann (2021), which uses a $254 \mathrm{~nm}$ G/uv silica gel plate as a stationary phase with a one-way developer system.

In TLC using hexane-EtOAc (1:1) developer phase and with $\mathrm{CHCl} 3$ spotting, samples showing 
spots with yellow and red-brown colors indicated the presence of a group of saponin compounds. TLC was also carried out using a developer BuOH-H2O (1:1), which will produce an absorption below $254 \mathrm{~nm}$, to compare the rf number of each extracted sample with standard saponins.

\section{Bioassays}

Biological testing of each $S$. sesban leaf extract fraction was carried out on gold snails as target organisms and on carp using an experimental design according to the APHA standard method (Clesceri et al., 2019) and on rice plants according to a completely randomized design (Einhellig \& Leather, 2018).

Prior to the biological test, a preliminary screening was carried out for each extract fraction, for gold snail, Goldfish, rice germination and rice plant growth, respectively, to determine the application concentration (6 concentration levels, including control), the results of which will be used for biological tests to determine $\mathrm{LC}_{50}$ (definitive screening) in each of these groups of test organisms.

The mortality variable of the test animals observed was the percentage of the number of test animals that died in each unit of the experimental sample. The observed rice germination variables were the percentage of germination and five-day radicle length. The observed rice growth variables included the number of tillers, plant height, leaf chlorophyll content and rice biomass 60 days after planting in each experimental unit. Each treatment extract concentration used 6 replications. In general, the study of the anti-mollus performance of S. sesban against gold snails, goldfish and rice plants can be seen in Figure 3.

\section{Data Analysis}

Each mortality data of golden snails and Goldfish was processed using the probit analysis according to Busvine-Nash (Suripto et al., 2015), with an $\mathrm{LC}_{50}$ output of each fraction of $S$. sesban leaf extract against gold snail and carp.

Each of paddy germination and growth data was processed non-statistically to see the germination and growth variables of the rice plant according to the variation of the extract treatment.
Specifically, the radicle length data, after being converted into the percentage of inhibition relative to the control, were then processed by probit analysis with the output of $\mathrm{EC}_{50}$ (effective concentration causing 50\% inhibition) of each fraction of S. sesban leaf extract on paddy germination.

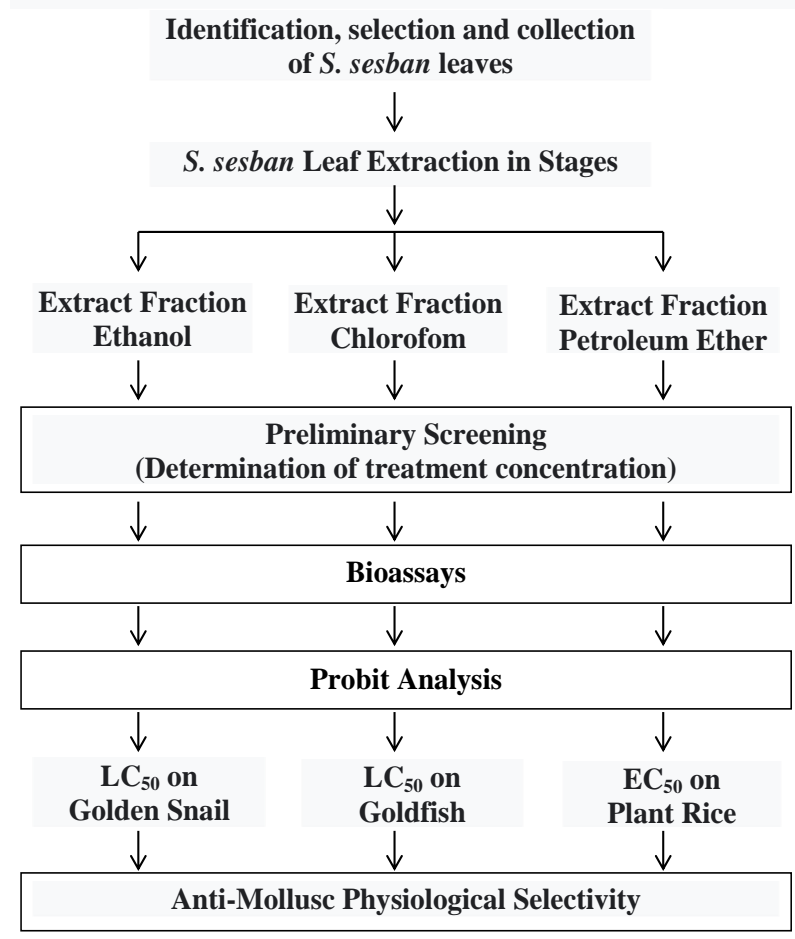

Figure 3. Workflow chart of evaluation of the anti-mollusk performance of S. sesban.

The data from probit analysis were further used to determine the physiological anti-mollusk selectivity of each of the leaf extract fractions of $S$. sesban, where golden snails were the target group of organisms, while Goldfish and paddy were the nontarget organisms, respectively. This anti-mollusk selectivity value can be calculated using the formula from Suripto et al. (2015) as follows:

$\mathrm{S}_{\text {for carp }}=\mathrm{LC}_{50}$ on goldfish $/ \mathrm{LC}_{50}$ on the golden snail

$\mathrm{S}_{\text {for paddy }}=\mathrm{EC}_{50}$ on paddy $/ \mathrm{LC}_{50}$ on the golden snail

The criteria used to determine the value of physiological selectivity of anti-mollusks are as follows:

If $S>1$, then the anti-mollusk properties of the tested extract have high selectivity or very selective 
If $\mathrm{S} \leq 1$, then the anti-mollusk properties of the tested extract have very low selectivity or nonselective.

Thus, the extract fraction with the highest physiological selectivity was declared the safest to be applied as a natural molluscicide in controlling golden snails from rice pests in the field.

The evaluation of the ecological selectivity of the use of physiologically selective extract fractions for the control of gold snails in the field is carried out in the "comprehensive evaluation" stage, which is to be carried out in the next year's research period.

\section{Results and Discussion}

\section{Determination of Application Concentration}

Preliminary experiments were carried out to determine the application concentration of each $S$. sesban leaf extract fraction.

Based on the results of the experiments, the application concentration level of each $S$. sesban leaf extract fraction was determined for the gold snail mortality test (Table 1), and the carp mortality test (Table 2).

Table 1. Application concentrations of various S. sesban leaf extract fractions used for bioassays on golden snails.

\begin{tabular}{lcccccc}
\hline $\begin{array}{l}\text { Extract } \\
\text { fraction: }\end{array}$ & \multicolumn{6}{c}{ Concentration (in ppm) } \\
\cline { 2 - 7 } & $\begin{array}{c}\mathrm{c}_{1} \\
\text { (Control) }\end{array}$ & $\mathrm{c}_{2}$ & $\mathrm{c}_{3}$ & $\mathrm{c}_{4}$ & $\mathrm{c}_{5}$ & $\mathrm{c}_{6}$ \\
\hline $\begin{array}{l}\text { Petroleum } \\
\text { eter }\end{array}$ & 0 & 200 & 250 & 275 & 300 & 350 \\
\hline Chloroform & 0 & 50 & 75 & 100 & 125 & 150 \\
\hline Ethanol & 0 & 15 & 20 & 25 & 28 & 30 \\
\hline
\end{tabular}

For the bioassays of $S$. sesban leaf extract on rice, the application concentrations were used as used in the biological test on the golden snails. This is in accordance with the aim of knowing the effect of the toxic effects of each $S$. sesban leaf extract fraction on rice plants at the same concentration as the concentration of the extract application on golden snails.
Table 1. Application concentrations of various S. sesban leaf extract fractions used for bioassays on goldfish.

\begin{tabular}{lcccccc}
\hline $\begin{array}{l}\text { Extract } \\
\text { fraction: }\end{array}$ & \multicolumn{6}{c}{ Concentration (in ppm) } \\
\cline { 2 - 7 } & $\begin{array}{c}\mathrm{c}_{1} \\
(\text { Control) }\end{array}$ & $\mathrm{c}_{2}$ & $\mathrm{c}_{3}$ & $\mathrm{c}_{4}$ & $\mathrm{c}_{5}$ & $\mathrm{c}_{6}$ \\
\hline $\begin{array}{l}\text { Petroleum } \\
\text { eter }\end{array}$ & 0 & 50 & 100 & 150 & 200 & 250 \\
\hline Chloroform & 0 & 25 & 50 & 75 & 100 & 125 \\
\hline Ethanol & 0 & 100 & 200 & 300 & 400 & 500 \\
\hline
\end{tabular}

The Mortality of Golden Snails in Various $S$. sesban Leaf Extract Fractions

The mortality of golden snail began to appear at a concentration of $200 \mathrm{ppm}$ in the treatment of petroleum ether extract fraction, at $75 \mathrm{ppm}$ chloroform extract fraction, and at $25 \mathrm{ppm}$ ethanol extract fraction. There was no gold snail death under the concentration of each extract fraction up to $4 \times 24$ hours of treatment. The golden snail mortality above $50 \%$ occurred at $275 \mathrm{ppm}$ of petroleum ether extract fraction, $75 \mathrm{ppm}$ of chloroform fraction, and $25 \mathrm{ppm}$ of ethanol fraction (Table 3).

Table 3. Mortality of golden snails at 72 hours treatment of each $S$. sesban leaf extract fraction

\begin{tabular}{|l|l|c|c|c|c|c|c|}
\hline \multirow{2}{*}{ PE Fraction } & $\begin{array}{l}\text { Cons. } \\
\text { (pp m) }\end{array}$ & 0 & 200 & 250 & 275 & 300 & 350 \\
\cline { 2 - 7 } & $\begin{array}{l}\text { Mort. } \\
(\%)\end{array}$ & 0,00 & 1,67 & 30 & 65,0 & 90 & 100 \\
\hline $\begin{array}{l}\text { Chloroform } \\
\text { Fraction }\end{array}$ & $\begin{array}{l}\text { Cons. } \\
\text { (pp m) }\end{array}$ & 0 & 50 & 75 & 100 & 125 & 150 \\
\cline { 2 - 7 } & $\begin{array}{l}\text { Mort. } \\
(\%)\end{array}$ & 0,00 & 0,00 & 78,3 & 96,7 & 98,3 & 100 \\
\hline \multirow{2}{*}{$\begin{array}{l}\text { Ethanol } \\
\text { Fraction }\end{array}$} & $\begin{array}{l}\text { Cons. } \\
(\text { pp m) }\end{array}$ & 0 & 15 & 20 & 25 & 28 & 30 \\
\cline { 2 - 7 } & $\begin{array}{l}\text { Mort. } \\
(\%)\end{array}$ & 0,00 & 0,00 & 10 & 60 & 88,3 & 96,7 \\
\hline
\end{tabular}

On the fifth day ( $5 \times 24$ hours of treatment), the golden snail's mortality in each extract fraction's treatment concentration did not change from the previous time. This indicates that the active content of anti-gold snail from each extract fraction is unstable in water, and on the fifth day, the molluscicide content is no longer active. 


\section{Goldfish Mortality in Various Treatments of $S$. sesban Leaf Extract Fraction}

Goldfish mortality began to appear at a concentration of $50 \mathrm{ppm}$ in the treatment of petroleum ether extract fraction, at $25 \mathrm{ppm}$ chloroform extract fraction, and at $200 \mathrm{ppm}$ ethanol extract fraction.

Under the concentration of each extract fraction up to 4 X 24 hours of treatment, there was no death of carp. Carp mortality above $50 \%$ occurred at $150 \mathrm{ppm}$ petroleum ether extract fraction, at 50 ppm chloroform fraction, and at $400 \mathrm{ppm}$ ethanol fraction (Table 4).

Table 4. Goldfish mortality at 72 hours treatment of various fractions of $\mathrm{S}$. sesban leaf extract (mean of 6 replications)

\begin{tabular}{|l|l|r|r|r|r|r|r|}
\hline $\begin{array}{l}\text { Petroleum } \\
\text { Eter } \\
\text { Fraction }\end{array}$ & $\begin{array}{l}\text { Kons. } \\
(\mathrm{ppm})\end{array}$ & 0 & 50 & 100 & 150 & 200 & 250 \\
\cline { 2 - 8 } & $\begin{array}{l}\text { Mort. } \\
(\%)\end{array}$ & 0,00 & 1,67 & 30 & 65,0 & 90 & 100 \\
\hline \multirow{2}{*}{$\begin{array}{l}\text { Chloroform } \\
\text { Fraction }\end{array}$} & $\begin{array}{l}\text { Kons. } \\
(\mathrm{ppm})\end{array}$ & 0 & 25 & 50 & 75 & 100 & 125 \\
\cline { 2 - 8 } & $\begin{array}{l}\text { Mort. } \\
(\%)\end{array}$ & 0,00 & 23,3 & 60,0 & 90,3 & 96,7 & 100 \\
\hline \multirow{2}{*}{$\begin{array}{l}\text { Ethanol } \\
\text { Fraction }\end{array}$} & $\begin{array}{l}\text { Kons. } \\
(\mathrm{ppm})\end{array}$ & 0 & 100 & 200 & 300 & 400 & 500 \\
\cline { 2 - 8 } & $\begin{array}{l}\text { Mort. } \\
(\%)\end{array}$ & 0,00 & 0,0 & 0,33 & 40,0 & 60,3 & 70,7 \\
\hline
\end{tabular}

Like the golden snail, the mortality of Goldfish on the fifth day in each treatment concentration of each extract fraction also did not change from the previous time. Thus, the content that was toxic to carp from each extract fraction seemed to be unstable in water, and the toxic content of the extract to carp on the fifth day was no longer active.

\section{Germination and Growth of Paddy in Various Treatments of $S$. sesban Leaf Extract Fractions.}

Each germination variable (percentage of the number of seeds that germinated and radicle length five days) and growth of rice plants 60 days after planting (number of tillers in a clump, leaf chlorophyll content, and biomass) were observed to be not significantly different according to variations in the concentration treatment of each extract fraction. Jayanti leaves (Figures 4, 5, and 6).

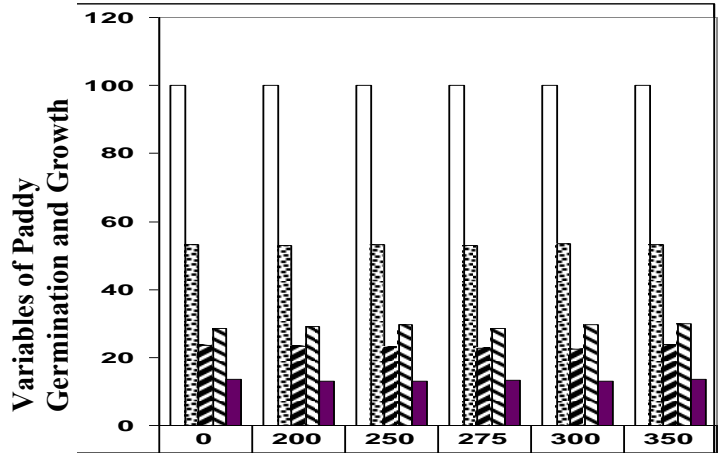

Extract Concentration (ppm)

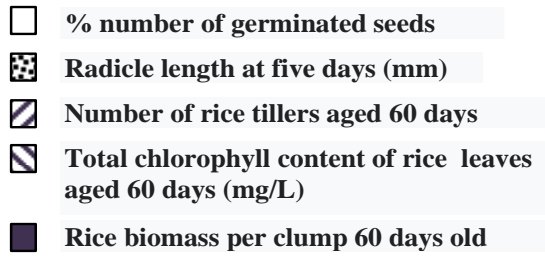

Figure 4. Variables of germination and growth of rice plants in the treatment of the petroleum ether extract fraction of $S$. sesban leaves.

The administration of $S$. sesban leaf extract, petroleum ether, chloroform, and ethanol fractions did not inhibit rice germination. This may be because the leaves of S. sesban do not contain or contain only very few compounds that affect the activity of hydrolytic enzymes and hormones such as IAA, which plays a role in the process of cell division, and G.A., which plays a role in the process of cell elongation in the germination process.

Stimulation of germination was determined by the activity of gibberellins or gibberellic acid (G.A.). G.A. is produced in the embryonic axis and partly diffuses into the aleurone layer, where hydrolysis enzymes are produced (Einhellig \& Leather, 2018).

According to Suripto et al. (2015), G.A. has two important roles in the germination process: stimulating the biosynthesis of hydrolysis enzymes and ribonucleases and mobilizing nutrients from the cotyledons, endosperm, and a little from the nucellus to areas that are actively growing, such as the radicle. The presence of G.A. in seeds exists in three forms: the free form (active) bound to sugar, protein or other substances (less active) and the form that turns into its derivatives such as alogibberellins, which are inactive. 


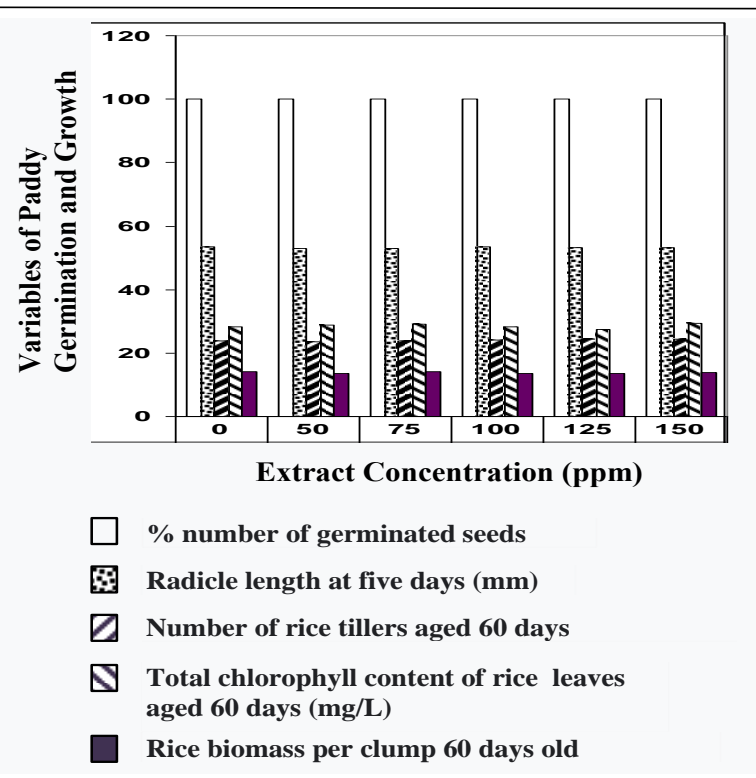

Figure 5. Variables of germination and growth of paddy in the chloroform extract fraction of S. sesban leaves treatment.

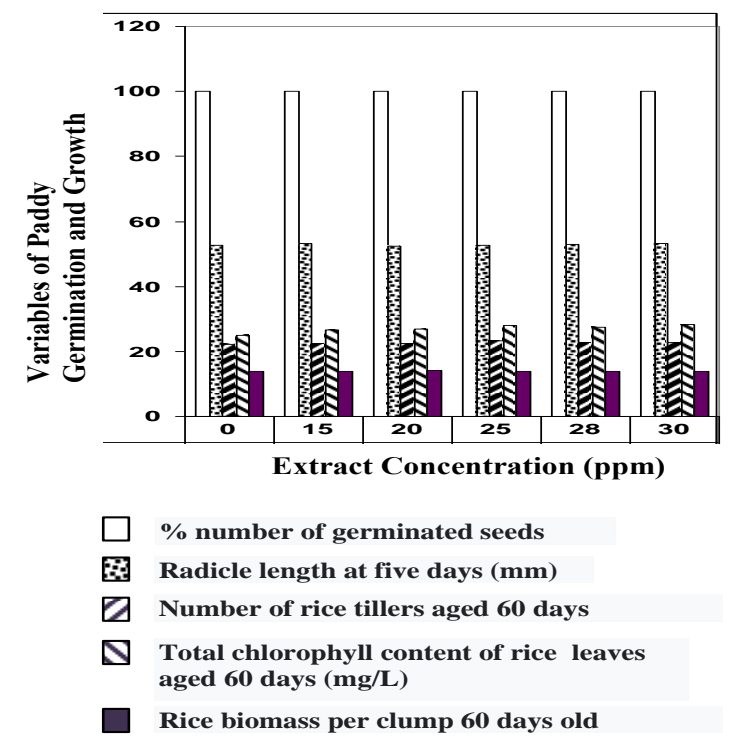

Figure 6. Variables of germination and growth of rice plants in the treatment of the ethanol extract fraction of $S$. sesban leaves.

\section{Physiological Selectivity of Each S. sesban Leaf Extract Fraction for Control of Golden Snails in Rice Plants}

Based on the results of probit analysis, it was found that all $S$. sesban leaf extract fractions studied had a lethal toxic effect on golden snails. The highest toxicity (lowest $\mathrm{LC}_{50}$ value) was indicated by the ethanol fraction, with an $\mathrm{LC}_{50}$ of 72 hours at 24.02 $\mathrm{ppm}$, then the lower toxicity was indicated by the chloroform and petroleum ether fractions, with an $\mathrm{LC}_{50}$ of 72 hours respectively 57, $20 \mathrm{ppm}$ and 263.68 ppm (Table 5).

Table 5. Summary of results of probit analysis of toxicity testing of various $S$. sesban leaf extract fractions against golden snails.

\begin{tabular}{|c|c|c|c|c|}
\hline & \multicolumn{3}{|c|}{ Extract Fraction } \\
\hline & & $\begin{array}{c}\text { Petroleum } \\
\text { ether }\end{array}$ & Chloroform & Ethanol \\
\hline \multicolumn{2}{|c|}{ LC $_{50} 72$ hours $(\mathrm{ppm})$} & 263,68 & 57,20 & 24,02 \\
\hline \multirow{2}{*}{$\begin{array}{l}\text { Feducial } \\
\text { limit LC }{ }_{50} \\
72 \text { hours } \\
(\mathrm{ppm})\end{array}$} & $\begin{array}{l}\text { Lower } \\
\text { limit }\end{array}$ & 249,46 & 33,48 & 22,32 \\
\hline & $\begin{array}{l}\text { Upper } \\
\text { limit }\end{array}$ & 278,71 & 97,73 & 25,85 \\
\hline \multicolumn{2}{|c|}{$\mathrm{LC}_{0} 72$ hours (ppm) } & 147,45 & 19,64 & 11,08 \\
\hline \multicolumn{2}{|c|}{ LC $_{100} 72$ hours (ppm) } & 345,72 & 131,12 & 33,20 \\
\hline
\end{tabular}

To assess the ecological quality of a pesticide, it is not only determined by its toxicity to the target organism of control but also the comparison of its toxicity to other organisms that are not the target of identification, such as the pest host plant itself or other microorganisms in the same place, which have benefits for humans. Suripto et al., 2015).

Based on the description of the criteria above, the ethanol extract fraction of Jayanti leaves in this study was considered to have the highest relative quality (highest physiological selectivity) for controlling golden snails from rice pests. The toxicity is high to gold snails as target organisms for identification but very low to other organisms that are not the target of control, such as carp and rice plants. In contrast, the other two fractions, namely the chloroform fraction and the petroleum ether fraction from this plant extract, each had lower toxicity to gold snails than to carp, as one of the components of non-target organisms.

Comparison of $\mathrm{LC}_{50}$ against gold snail, carp, and rice plants from each $S$. sesban leaf extract fraction can be seen in Table 6 . 
Table 6. Comparison of the toxicity of various $S$. sesban leaf extract fractions to gold snails, Goldfish, and paddy.

\begin{tabular}{llll}
\hline Extract Fraction & $\begin{array}{l}\mathrm{LC}_{50} \text { on } \\
\text { Golden } \\
\text { Snail }(\mathrm{ppm})\end{array}$ & $\begin{array}{l}\mathrm{LC}_{50} \text { on } \\
\text { Goldfish } \\
(\mathrm{ppm})\end{array}$ & $\begin{array}{l}\mathrm{EC}_{50} \text { on } \\
\text { Paddy } \\
(\mathrm{ppm})\end{array}$ \\
\hline Petroleum Ether & 363.68 & 188.00 & 1500.00 \\
\hline Chloroform & 57.20 & 44.60 & 1900.50 \\
\hline Etahnol & 24.02 & 350.00 & 2000.80 \\
\hline
\end{tabular}

A pesticide with very high toxicity to pests but not toxic or very low toxicity to non-target organisms is said to have high selectivity or a narrow spectrum of toxic effects. With this, the ethanol fraction of Jayanti leaf extract in this study was considered to have the highest anti-mollusk selectivity compared to the other two fractions for controlling golden snails for rice plant pests. The selectivity values for antigold snails from each Jayanti leaf extract fraction, using carp and rice plants respectively as non-target organisms, can be seen in Table 7 .

Table 7. Selectivity value (S) of anti mollusks from various $S$. sesban leaf extract fractions (gold snail as the target organism)

\begin{tabular}{lcc}
\hline Extract Fraction & \multicolumn{2}{c}{ Non-Target Organisms } \\
\cline { 2 - 3 } & Goldfish & Paddy \\
\hline Petroleum Ether & 0,52 & 4,13 \\
\hline Chlorofom & 0,78 & 33,23 \\
\hline Ethanol & 14,57 & 83,30 \\
\hline
\end{tabular}

The anti-mollusk properties, in this case, the toxicity to golden snails from the leaf extract of $\mathrm{S}$. sesban, were made possible by saponins in the extract. Examination of the bioactive extract showed the presence of triterpene saponins with the highest relative content in the ethanol fraction compared to the chloroform and petroleum ether fractions. On shaking the extract solution in the test tube, there was a steady foam formation in the ethanol fraction extract sample (foam height was more than $3 \mathrm{~cm}$ ).

According to Hamburger \& Hostettmann (2021), such symptoms indicate the presence of the saponin group. In the chloroform and petroleum ether samples, relatively little foam was formed (the height of the foam in the tube was less than $1 \mathrm{~cm}$ ), and the foam disappeared after being added with $10 \% \mathrm{HCl}$. The results of this foam test are supported by the results of thin-layer chromatography (TLC).

In TLC with hexane-EtOAc (1:1) developer, the chromatogram showed yellow and brown spots in all samples of the extract fraction. According to Suripto, et al. (2015), such symptoms indicate the presence of a triterpene saponin group. In TLC with $\mathrm{BuOH}-\mathrm{H} 2 \mathrm{O}$ as a developer, the chromatogram showed absorption under UV $254 \mathrm{~nm}$. One of the absorptions with the same Rf value as standard saponins was from the ethanol fraction extract sample $($ Rf value $=0.0600)$. In chloroform and petroleum ether samples, the absorption is not clear.

From the results of the bioactive tests above, it can be concluded that the three-leaf extract fractions of S. sesban each contain triterpene saponins with the highest relative levels in the ethanol fraction. From these instructions, it can also be concluded that the toxicity of $S$. sesban leaf extract to golden snails is related to the saponin content of the extract. Bioactives in the form of saponins from $S$. sesban leaves have previously been shown to be lethally toxic to several other freshwater snail species, such as Biomphalaria glabgrata (Kloos \& McCullough, 2017) and Bulinus truncatus (Farnsworth et al., 2017).

According to Mahato \& Nandy (2021), the molluscicidal activity of saponins is related to the ability to affect cell membranes, which causes various snail reactions due to contact with or due to consuming saponin compounds. The snail's reaction to the molluscicide action of saponins is initiated by producing and secreting mucus to further reduce the contact of its body surface with the molluscicide. However, the formation of excessive amounts of mucus can inhibit breathing in which the mucus blocks the diffusion of oxygen through the gills.

Although very toxic to golden snails, the ethanol fraction of $S$. sesban leaf extract with a concentration that can kill carp snails did not cause death in Goldfish. This is because Goldfish treated with extracts can respond behaviorally by accelerating their gill movements and swimming activity, which can compensate for respiratory resistance due to the closure of the gills by excessive 
mucus as a physiological response of fish to the presence of saponins (Takechi et al., 2021).

In addition, the presence of saponins in this extract may also stimulate tissues in the digestive system to secrete hydrolytic enzymes, which can neutralize these toxic compounds (saponins), as previously reported by Brain et al. (2020) and Francis et al. (2012). Thus, the application of the ethanol fraction of the leaf extract of $S$. sesban for controlling Goldfish in rice fields, apart from being safe for rice germination and growth, is also safe for carp.

\section{Conclusions}

Three extract fractions of . sesban leaf, namely the petroleum ether, -chloroform and -ethanol extraxt fraction, each had a lethal toxic effect on golden snails. However, only the ethanol fraction has high selectivity for controlling golden snails with Goldfish as non-target animals. The three leaf extract fractions of $S$. sesban each had very low toxicity to the germination and growth of rice plants. The toxicity of S. sesban leaf extract to golden snails was related to the saponin content. The three leaf extract fractions of $S$. sesban contained triterpene saponins, with the highest relative levels in the ethanol fraction.

To further evaluate the physiological selectivity of anti-Mollusca from this Jayanti plant, it is also necessary to carry out biological tests on other nontarget organisms from the class of mammals, aves, and other types of snails that are not pests that are common or often found in rice fields.

This class of saponins, which are active as antimollusca ingredients from the leaves of the $S$. sesban plant, needs to be studied further to determine the "mode of action" or its chemical structure for the development of the application of this natural molluscicide on a larger industrial scale. In addition, it is also necessary to conduct a field evaluation to determine the ecological selectivity of the antimollusk properties of this Jayanti plant. Thus, it will be possible to study the modification of manufacturing techniques and the application of molluscicide materials from Jaanti plants that are feasible for farmers to control the golden snail pest of rice plants.

\section{Acknowledgment}

This research is fully supported and funded by the Ministry of Research, Technology and Higher Education, the Republic of Indonesia through The Institute for Research and Community Service and Faculty of Mathematics and Natural Sciences, University of Mataram. Also, thanks are given to environmental science students at the Biology Study Program of the Faculty of Mathematics and Natural Sciences, University of Mataram, even semester of the academic year 2020/20121.

\section{References}

Adalla, C.B. \& B. Morrallo-Rejeus (2019). The golden apple snail, Pamacea sp. A pest of lowland rice in the Philippines. In : Sluges and Snails in World Agriculture ( Ed.:I Henderson). British Crop Protection Council.London. p: 417-422.

Brain, K., Hadgraft, J. \& E.M. Al-shatalebi (2020). Membrane modification in activity of plant molluscicides. Planta Med. 56:663-664.

Clesceri, L.S., Greenberg, A.E. \& R.R Trussel (2019). Standard Methods for Examination of Water and Wastewater. APHA. New York, Washington DC.

Cybermedia (2017). Keong mas serang tanaman padi. Kompas Cybermedia (24-01-2017). http://www.kompas.com

Duncan, J. (2017). The biochemical and phyisilogical basis of the mode of action of molluscicides. In: Plant Molluscicides (Eds: B.O Acosta \& K.E. Mott). John Wiley and Sons Ltd Chichester.New York. Brisbane. Toronto. Singapore. P: 27-44.

Edra, F.A. (2019). Introduction of the golden snail and escalation of its infestation of Philippine riceland. In: Environmental Impact of The Golden Snail ( Pomacea sp.) on Rice Farming System in The Philippines (Eds.: B.O. Acosta \& R.S.V.Pullin ). International Center for Living Aquatic Resources Management. Manila p: 11-12. 
Einhellig, F.A. \& G.R Leather (2018). Bioassay of naturally occuring allelochemical for phytotoxicity. J. Chem. Ecol. 5:815-824.

Farnsworth, N.R., Henderson, T.O. \& D.D. Soejarto (2017).'Plant with potential molluscicidal activity. In: Plant Molluscicides (Eds.: B.O. Acosta \& K.E. Mott). John Wiley and Sons Ltd. Chichester. New York. Brisbane.Toronto. Singapore. p:131-204.

Francis,G., Kerem, Z., Makkar, H.P.S. \& K. Becker (2012). The biological action of saponins in animal systems: A review. British J. of Nutrition. 88: 587-605.

Guerrero, L. (2019). The biology og the golden snail in relation to Philippine conditions. In: Environmental Impact of The Golden Snail ( Pomacea sp.) on Rice Farming System in The Philippines ( Eds.: B.O. Acosta \& R.S.V.Pullin ). International Center for Living Aquatic Resources Management. Manila p: 10-11.

Hamburger, M. \& K. Hostettmann (2021). Bioactivity in plants: The link between phytochemistry and medicine phytochemistry. Phytochemistry. 30 (12):3864-3874.

Hostettmann, K., Kizu, H \& T Tomimori (2012) Molluscicidal properties of various saponins. Planta Med. 44:34-35.

Kloos, H. \& F.S. McCullough (2017). Plant with recognized molluscicidal activity. In: Plant Molluscicides (Eds.: B.O. Acosta \& K.E. Mott). John Wiley and Sons Ltd. Chichester.
New York. Brisbane.Toronto. Singapore. $\mathrm{p}: 45-108$.

Lacanilao, F. (2020). Reproduction of the golden apple snail, egg mass, haching, and incubation. Philipp. J. Sci. 119 (2):95-105.

Mahato, S.B. \& A.K. Nandy (2021). Triterpenoid saponins discovered between 2017 and 2019. Phytochemistry. 30 (5):1357-1390.

Munandar, A. (2013). Serba-serbi Keong Murbei dan Keong Mas. Laporan tidak dipublikasikan. Balai Penelitian dan Pengembangan Zoologi. LIPI.

Sturrock, R.F. \& J. Duncan (2017). Field evaluation of potential plant molluscicides. In: Plant Molluscicides (Eds.: B.O. Acosta \& K.E. Mott). John Wiley and Sons Ltd. Chichester. New York. Brisbane.Toronto. Singapore. p:267-288.

Sumangil, J.P. (2019). Biological control. In: Environmental Impact of The Golden Snail ( Pomacea sp.) on Rice Farming System in The Philippines ( Eds.: B.O. Acosta \& R.S.V.Pullin). International Center for Living Aquatic Resources Management. Manila p: 26-27.

Suripto, Tresnani, G. \& H.A. Jupri (2015). Spektrum Efek Toksik dari Berbagai Fraksi Ekstrak Daun Jayanti. (Laporan Peneltian tidak dipublikasikan). Lembaga Penelitian Universitas Mataram.

Takechi, M., Shimada, S. \& Y. Tanaka (2021). Time course and inhibition of saponin-induced haemolysis. Planta Med. 58:128-130. 